\title{
Article \\ Gossypol Exhibited Higher Detrimental Effect on Ruminal Fermentation Characteristics of Low-Forage in Comparison with High-Forage Mixed Feeds
}

\author{
Wei-Kang Wang (D), Yan-Lu Wang, Wen-Juan Li, Qi-Chao Wu, Sheng-Li Li and Hong-Jian Yang *(D) \\ State Key Laboratory of Animal Nutrition, College of Animal Science and Technology, China Agricultural \\ University, Beijing 100193, China; 18292092306@163.com (W.-K.W.); wang_yanlu@cau.edu.cn (Y.-L.W.); \\ liwjuan1226@163.com (W.-J.L.); wuqichao@cau.edu.cn (Q.-C.W.); lisheng0677@163.com (S.-L.L.) \\ * Correspondence: yang_hongjian@sina.com
}

check for updates

Citation: Wang, W.-K.; Wang, Y.-L.; Li, W.-J.; Wu, Q.-C.; Li, S.-L.; Yang, H.-J. Gossypol Exhibited Higher Detrimental Effect on Ruminal Fermentation Characteristics of Low-Forage in Comparison with High-Forage Mixed Feeds. Toxics 2021, 9, 51. https://doi.org/ $10.3390 /$ toxics 9030051

Academic Editor: Thomas J. Sharpton

Received: 3 February 2021

Accepted: 2 March 2021

Published: 8 March 2021

Publisher's Note: MDPI stays neutral with regard to jurisdictional claims in published maps and institutional affiliations.

Copyright: (c) 2021 by the authors. Licensee MDPI, Basel, Switzerland. This article is an open access article distributed under the terms and conditions of the Creative Commons Attribution (CC BY) license (https:/ / creativecommons.org/licenses/by/ $4.0 /)$.

\begin{abstract}
Gossypol is a key anti-nutritional factor which limits the feeding application of cottonseed by-products in animal production. A $2 \times 4$ factorial in vitro experiment was conducted to determine the effect of gossypol addition levels of $0,0.25,0.5$, and $0.75 \mathrm{mg} / \mathrm{g}$ on ruminal fermentation of a high-forage feed $(\mathrm{HF}$, Chinese wildrye hay/corn meal = 3:2) in comparison with a low-forage feed $(\mathrm{LF}$, Chinese wildrye hay/corn meal $=2: 3$ ). After $48 \mathrm{~h}$ of incubation, in vitro dry matter disappearance was greater in the LF than the HF group, while the cumulative gas production and asymptotic gas production were greater in the HF than the LF group $(p<0.05)$. Regardless of whatever ration type was incubated, the increasing gossypol addition did not alter in vitro dry matter disappearance. The asymptotic gas production, cumulative gas production, molar percentage of $\mathrm{CO}_{2}$ and $\mathrm{H}_{2}$ in fermentation gases, and microbial protein in cultural fluids decreased with the increase in the gossypol addition. Conversely, the gossypol addition increased the molar percentage of $\mathrm{CH}_{4}$, ammonia $\mathrm{N}$, and total volatile fatty acid production. More than $95 \%$ of the gossypol addition disappeared after $48 \mathrm{~h}$ of in vitro incubation. Regardless of whatever ration type was incubated, the real-time PCR analysis showed that the gossypol addition decreased the populations of Fibrobacter succinogenes, Ruminococcus albus, Butyrivibrio fibrisolvens, Prevotella ruminicola, Selenomonas ruminantium, and fungi but increased Ruminococcus flavefaciens, protozoa, and total bacteria in culture fluids in comparison with the control $(p<0.01)$. Additionally, the tendency of a smaller population was observed for R. albus, B. fibrisolvens, and fungi with greater inclusion of gossypol, but a greater population was observed for F. succinogenes, R. flavefaciens, S. ruminantium, protozoa, and total bacteria. In summary, the present results suggest that rumen microorganisms indeed presented a high ability to degrade gossypol, but there was an obvious detrimental effect of the gossypol addition on rumen fermentation by decreasing microbial activity when the gossypol inclusion exceeded $0.5 \mathrm{mg} / \mathrm{g}$, and such inhibitory effect was more pronounced in the low-forage than the high-forage group.
\end{abstract}

Keywords: gossypol; in vitro fermentation; rumen microbes

\section{Introduction}

Gossypol $\left(\mathrm{C}_{30} \mathrm{H}_{30} \mathrm{O}_{8}\right)$, a polyphenolic compound found in the cotton plant (Gossypium sp.) [1], is commonly regarded as one of the key anti-nutritional factors that limit the feeding application of cottonseed by-products (e.g., whole cottonseed, cottonseed meal) in animal production. In the animal nutritionist community, adult ruminants with mature microbial fermentation functionality in the rumen are commonly considered more tolerant to gossypol than monogastric animals and young ruminants [2]. For a long time, the current knowledge has believed that the high tolerance to gossypol by adult ruminants should be attributable to microbial detoxification in the rumen via binding to soluble proteins and microbial degradation $[3,4]$. Clinical signs of high gossypol intake on host animals in terms of erythropoiesis [5,6], milk performance [7], and postpartum estrus in dairy cows [8] and 
sperm production in bulls [9-11] have been well recognized, and the maximal tolerant gossypol intake limit in feeds $(<500 \mathrm{mg} / \mathrm{kg})$ has been set for different farm animals in feeding practice in the European Union [12].

The rumen microbiome is a highly diverse collection of obligately anaerobic microbes including fungi, protozoa, bacteria, and archaea [13]. The rumen fermentation response to gossypol exposure has not been well described until now, and it was not clear if the tolerance of rumen microbes to gossypol could differ depending on the forage to concentrate ratio. In the present study, the objective is threefold: firstly, to determine how much gossypol could be degraded; secondly, to investigate if an increasing gossypol addition could inhibit rumen fermentation characteristics; and, finally, to clarify if the detrimental effect could differ depending on the forage level in diets.

\section{Materials and Methods}

\subsection{Gossypol Solution Preparation}

Forty mg of gossypol chemical ( $>97 \%$, Sigma-Aldrich, Darmstadt, Germany) was dissolved in $2 \mathrm{~mL}$ glacial acetic acid to serve as a standard gossypol solution. Prior to the experiment, the solution was diluted with glacial acetic acid to obtain three working solutions containing 5,10 , and $15 \mathrm{mg} / \mathrm{mL}$ gossypol, respectively.

\subsection{Rumen Fluid Preparation}

All animal experimental procedures were conducted in accordance with the Institutional Animal Care Committee of China Agricultural University (CAU20171014-1). Three middle lactating Holstein cows (daily milk yield of $20.5 \pm 0.9 \mathrm{~kg}$ ) were used as rumen fluid donors. These rumen-fistulated cows had free access to water and were fed with $12.5 \mathrm{~kg}$ total mixed ration with $520 \mathrm{~g} / \mathrm{kg}$ dry matter (DM) content twice daily at 07:00 a.m. and 05:00 p.m. The ration consisted of $490 \mathrm{~g}$ maize silage, $110 \mathrm{~g}$ alfalfa hay, $140 \mathrm{~g}$ maize meal, $260 \mathrm{~g}$ commercial concentrate per $\mathrm{kg}$ of DM. Rumen fluid from each cow was collected $2 \mathrm{~h}$ after the morning feeding and squeezed through four layers of cheesecloth. The filtrated rumen fluids from the three cows were mixed in equal proportion and filled with $\mathrm{CO}_{2}$ at $39^{\circ} \mathrm{C}$ in a water bath prior to in vitro inoculation.

\subsection{Experimental Design and In Vitro Incubation}

Following a $2 \times 4$ factorial in vitro experimental design, a high-forage mixed substrate (HF, Chinese wildrye hay/corn meal-3:2, w/w) and a low-forage mixed substrate (LF, Chinese wildrye hay/corn meal-2:3, w/w) were prepared in the present study. Afterwards, each of the above substrates was incubated in vitro with gossypol inclusion at $0,0.25,0.5$, and $0.75 \mathrm{mg} / \mathrm{g}$ substrate on DM basis. The chemical composition of two rations is shown in Table 1.

Table 1. Chemical composition of two substrates (\%, DM).

\begin{tabular}{ccc}
\hline Item $^{\mathbf{1}}$ & HF & LF \\
\hline Crude protein & 7.5 & 8.0 \\
Neutral detergent fiber & 45.0 & 33.0 \\
Acid detergent fiber & 25.6 & 18.4 \\
Ether extract & 3.5 & 4.0 \\
Starch & 28.4 & 41.2 \\
\hline
\end{tabular}

${ }^{1} \mathrm{HF}$, high-forage substrate; LF, low-forage substrate.

For each substrate, $500 \mathrm{mg}$ substrate was placed into 40 bottles (4 gossypol addition levels $\times 10$ replicates_-40 bottles per substrate) with $50 \mathrm{~mL}$ buffer solution (pH 6.87) [14] and $25 \mathrm{~mL}$ filtered rumen fluid. The gossypol working solutions $(25 \mu \mathrm{L})$ were added to these bottles, resulting in the three afore mentioned gossypol treatment levels, and $25 \mu \mathrm{L}$ gossypol-free glacial acetic acid solution was added to the control group for each substrate. All of these bottles were purged with anaerobic $\mathrm{N}_{2}$ to obtain an anaerobic condition and 
sealed with butyl rubber stoppers and Hungate's screw caps. For each substrate, 20 bottles (4 gossypol addition levels $\times 5$ replicates -20 bottles per substrate) were individually connected to an automated gas production recording system (AGRS-III, China Agricultural University, Beijing, China) [15] and incubated at $39{ }^{\circ} \mathrm{C}$ for $48 \mathrm{~h}$. Simultaneously, an additional 20 bottles ( 4 gossypol addition levels $\times 5$ replicates -20 bottles per substrate) prepared in the same manner were separately connected to pre-emptied air bags and incubated at the same condition as above for later analysis of gas composition.

\subsection{Sampling and Analysis}

2.4.1. Sample Collection

After $48 \mathrm{~h}$ of incubation, all bottles were disconnected from the AGRS-III system and air bags. The $\mathrm{pH}$ values in culture fluids were measured immediately. The remaining biomasses of each bottle were separately filtered through pre-weighed nylon bags. The bags containing filtrated residues were then rinsed in tap water until the water ran clear, then squeezed by hand to remove excess water, and dried at $65^{\circ} \mathrm{C}$ for $24 \mathrm{~h}$ for in vitro dry matter disappearance (IVDMD) analysis. One sample of $1 \mathrm{~mL}$ culture fluids from each bottle was mixed with $0.3 \mathrm{~mL}$ of $250 \mathrm{~g} / \mathrm{L}$ meta-phosphoric acid solution at $4{ }^{\circ} \mathrm{C}$ for $30 \mathrm{~min}$ and centrifuged at $10,000 \times \mathrm{g}$ for $15 \mathrm{~min}$ at $4{ }^{\circ} \mathrm{C}$. The supernatants were kept at $-20^{\circ} \mathrm{C}$ for later analysis of volatile fatty acids (VFAs) and ammonia $\mathrm{N}$. Three samples $(1 \mathrm{~mL} \times 3)$ of culture fluids were stored at $-20^{\circ} \mathrm{C}$ for gossypol and microbial protein (MCP) analysis. Additionally, a sample of $1 \mathrm{~mL}$ culture fluids was stored at $-80^{\circ} \mathrm{C}$ for the analysis of microbial population.

\subsubsection{Chemical Analysis and Calculations}

Crude protein, ether extract, and starch were determined according to the methods of AOAC [16]. Neutral detergent fiber and acid detergent fiber were determined according to the methods of Van Soest et al. [17]. Ammonia N and MCP concentrations were determined by spectrophotometry according to the methods of Verdouw et al. [18] and Cui et al. [19], respectively. The VFAs concentration and fermentation gas composition were determined by gas chromatography according to the methods of Zhang and Yang [15] and Cui et al. [19], respectively.

Cumulative GP data [GP( $\mathrm{t}), \mathrm{mL} / \mathrm{g} \mathrm{DM}]$ at time $(\mathrm{t})$ were fitted to a nonlinear model [20] by iterative regression analysis, as shown in Equation (1):

$$
\mathrm{GP}(\mathrm{t})=\mathrm{A} /\left[1+(\mathrm{C} / \mathrm{t})^{\mathrm{B}}\right]
$$

where A represents the asymptotic GP generated at a constant fractional rate (c) per unit time, $t$ is the time of the gas recording, $\mathrm{B}$ is a sharpness parameter determining the shape of the curve, and $\mathrm{C}$ is the time (h) at which half of $\mathrm{A}$ is reached. The value of $\mathrm{A}-\mathrm{C}$ was estimated using the nonlinear procedure of SAS [21]. The average GP rate (AGPR) at half of A was calculated according to Equation (2):

$$
\mathrm{AGPR}=(\mathrm{A} \times \mathrm{B}) /(4 \times \mathrm{C})
$$

Isobutyrate and isovalerate were summed as branched-chain VFAs (BCVFA). The ratio of non-glucogenic-to-glucogenic acids (NGR) was calculated [22] as Equation (3):

$$
\mathrm{NGR}=(\text { acetate }+2 \times \text { butyrate }+ \text { valerate }) /(\text { propionate }+ \text { valerate })
$$

where VFAs were expressed in molar proportion.

Fermentation efficiency (FE) of energy from carbohydrates to VFAs was estimated using Equation (4):

$\mathrm{FE}=(0.622 \times$ acetate $+1.092 \times$ propionate $+1.56 \times$ butyrate $) /($ acetate + propionate $+2 \times$ butyrate $)$ 


\subsubsection{Gossypol Extraction and High-Performance Liquid Chromatography Analysis}

Gossypol in rumen fluid samples was extracted according to the method described by Zhong [23]. The contents of gossypol were quantified by high-performance liquid chromatography using a Wufeng analytical instrument (Wufeng Co., Ltd., Shanghai, China) consisting of an LC-P100PLUS pump, LC-UV100PULS UV detector, LC-CO100PLUS column heater, and a symmetry reversed-phase C18 column $(250 \times 4.6 \mathrm{~mm}, 5 \mu \mathrm{m}, \mathrm{pH} 2-8$, Waters, Milford, MA, USA). The method was set as follows: The mobile phase was acetonitrile and $0.2 \%$ phosphoric acid solution at a ratio of 85:15 $(\mathrm{v} / \mathrm{v})$ under a flow rate of $1 \mathrm{~mL} / \mathrm{min}$. Injections were $20 \mu \mathrm{L}$, and gossypol was detected at $235 \mathrm{~nm}$ with an analysis temperature of $25^{\circ} \mathrm{C}$.

An amount of $100 \mathrm{mg}$ standard gossypol was dissolved into $1 \mathrm{~mL}$ mobile phase and diluted to $100,50,25,12.5,6.25,3.125,1.55,0.78,0.36,0.18$, and $0.09 \mu \mathrm{g} / \mathrm{mL}$ by mobile phase. The standard curve (Figure 1) was obtained by linear regression of the peak area (Y) and gossypol concentration $(\mathrm{X})$ under optimal chromatographic conditions as noted above. Gossypol standards shown peaked at a retention time of $5 \mathrm{~min}$.

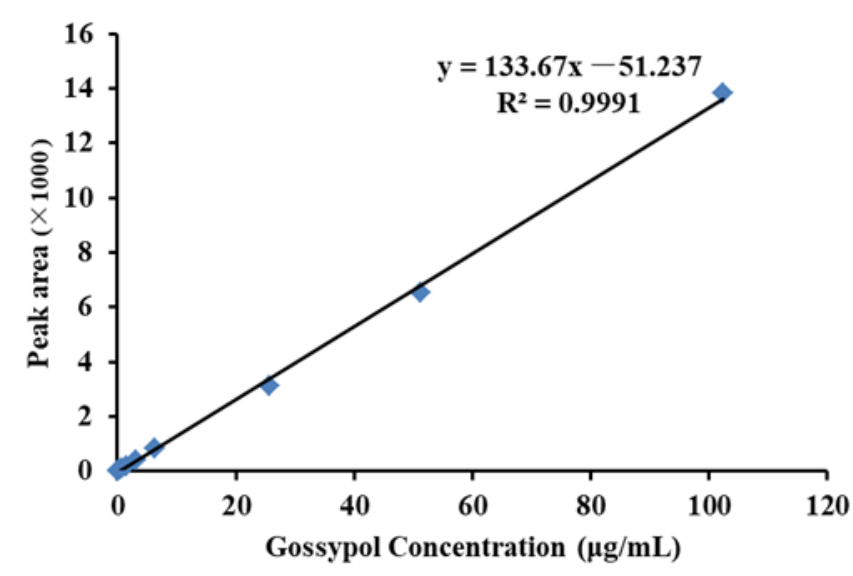

Figure 1. Standard curve of gossypol.

\subsubsection{DNA Extraction and Real-Time PCR Amplification of 16S RNA Genes}

The populations of protozoa, fungi, total bacteria, and six major bacteria (Fibrobacter succinogenes, Ruminococcus flavefaciens, Ruminococcus albus, Butyrivibrio fibrisolvens, Prevotella ruminicola, Selenomonas ruminantium) were determined by qPCR. The total DNA of the rumen fluid sample was extracted by using the QIAamp ${ }^{\circledR}$ DNA stool mini kit (Qiagen, Hilden, Germany) following the manufacturer's instructions. The concentration of total DNA from each sample was estimated using a Nanodrop spectrophotometer 2000 (Thermo Scientific, Wilmington, DE, USA) at $260 \mathrm{~nm}$.

Quantitative PCR was conducted with ABI 7500 FAST real time PCR system (ABI 7500, Applied Biosystems, Foster City, CA, USA) using TB Green Premix Ex Taq II (Tli RNaseH Plus) (Takara, Dalian, Liaoning, China). The total volume of amplification reactions was $50 \mu \mathrm{L}$, including $4 \mu \mathrm{L}$ of template DNA, $25 \mu \mathrm{L}$ of TB Green Premix Ex Taq II (Tli RNaseH Plus) $(2 \times), 1 \mu \mathrm{L}$ of ROX Reference Dye $(50 \times), 2 \mu \mathrm{L}$ of each primer $(10 \mathrm{pmol} / \mu \mathrm{L})$, as shown in Table 1, and $16 \mu \mathrm{L}$ sterile $\mathrm{H}_{2} \mathrm{O}$. The cycling conditions contained the following: an initial denaturation step at $95^{\circ} \mathrm{C}$ for $30 \mathrm{~s}$, followed by 40 cycles of $95^{\circ} \mathrm{C}$ for $3 \mathrm{~s}$ and $60^{\circ} \mathrm{C}$ for $30 \mathrm{~s}$. Dissociation curve of PCR end products was used for judging the amplification specificity. All PCRs were performed in triplicate. The normalized fluorescence data were converted to a log scale and the threshold cycle value was calculated by determining the threshold (Ct; the cycle at which the threshold line crosses the amplification curve).

\subsubsection{Preparation of Standard Plasmid for Real-Time PCR}

The target DNA was amplified by absolute quantification PCR using plasmid DNA containing the respective target gene sequence as standard DNA, and the species-specific 
primer sets used are shown in Table 2. The PCR product sizes were confirmed by agarose gel and purified using the QIAquick gel extraction kit (Qiagen, Valencia, CA, USA). Then, the PCR products were ligated into pTZ57RT cloning vector (Fermentas, Berlin, Germany), and we transformed the ligated products into competent Escherichia coli DH5 alpha cells by heat shock. The plasmids were purified from positive clones and confirmed by PCR amplification with the respective primer sets. The concentration of the target DNA was determined by Nanodrop spectrophotometer 2000 (Thermo Scientific, Wilmington, USA). Copy number per $\mu \mathrm{L}$ of standard plasmid was calculated based on the formula: Copy $\mathrm{No} / \mu \mathrm{L}=$ Concentration of plasmids $(\mathrm{g} / \mu \mathrm{L}) \times 6.022 \times 10^{23} /$ length of recombinant plasmid (bp) $\times 660,\left(660=\right.$ Molecular weight of one basepair, $6.022 \times 10^{23}=$ Avogadro's number). The amplification of each ample as well as the 10-fold dilution series of the standard plasmid ranging from $10^{11}$ to $10^{5}$ copies for the respective target DNA was run in triplicate.

Table 2. Primers for real-time PCR.

\begin{tabular}{|c|c|c|c|}
\hline Target Groups & Sequence $5^{\prime}-3^{\prime}$ & Product Size (bp) & References \\
\hline F. succinogenes & $\begin{array}{l}\text { F: GTTCGGAATTACTGGGCGTAAA } \\
\text { R: CGCCTGCCCCTGAACTATC }\end{array}$ & 121 & [24] \\
\hline R. flavefaciens & $\begin{array}{l}\text { F:CGAACGGAGATAATTTGAGTTTACTTAGG } \\
\text { R:CGGTCTCTGTATGTTATGAGGTATTACC }\end{array}$ & 132 & [24] \\
\hline R. albus & $\begin{array}{l}\text { F: CCCTAAAAGCAGTCTTAGTTCG } \\
\text { R: CCTCCTTGCGGTTAGAACA }\end{array}$ & 175 & [25] \\
\hline B. fibrisolvens & $\begin{array}{l}\text { F:TAACATGAGAGTTTGATCCTGGCTC } \\
\text { R:CGTTACTCACCCGTCCGC }\end{array}$ & 136 & [26] \\
\hline P. ruminicola & $\begin{array}{l}\text { F:GAAAGTCGGATTAATGCTCTATGTTG } \\
\text { R:CATCCTATAGCGGTAAACCTTTGG }\end{array}$ & 74 & [27] \\
\hline S. ruminantium & $\begin{array}{l}\text { F:CAATAAGCATTCCGCCTGGG } \\
\text { R:TTCACTCAATGTCAAGCCCTGG }\end{array}$ & 138 & [27] \\
\hline Protozoa & $\begin{array}{l}\text { F:GCTTTCGWTGGTAGTGTATT } \\
\text { R:CTTGCCCTCYAATCGTWCT }\end{array}$ & 223 & [28] \\
\hline Fungi & $\begin{array}{l}\text { F:GAGGAAGTAAAAGTCGTAACAAGGTTTC } \\
\text { R:CAAATTCACAAAGGGTAGGATGATT }\end{array}$ & 120 & [24] \\
\hline Total bacteria & $\begin{array}{l}\text { F:CGGCAACGAGCGCAACCC } \\
\text { R:CCATTGTAGCACGTGTGTAGCC }\end{array}$ & 146 & [25] \\
\hline
\end{tabular}

\subsection{Statistical Analysis}

All the experimental data, including the interaction effect of rations and gossypol addition levels, were analyzed by using the general linear model procedure of SAS (1999) with a multiple comparison test (Tukey/Kramer). The linear and quadratic polynomial contrasts were used to examine responses of different rations for increasing gossypol addition levels by ANOVA. Significance was declared at $p<0.05$ unless otherwise noted.

\section{Results and Discussion}

\subsection{Effect of Gossypol on IVDMD and Kinetic Gas Production}

In the present study, two rations used were designed to simulate the forage to concentrate ratios of cows at different stages of lactation, and the purpose of the four gossypol addition levels used was to study the effect of gossypol concentrations below or above the safety limit $(500 \mathrm{mg} / \mathrm{kg}$ ) on rumen fermentation characteristics and the population of rumen microbes. As shown in Table 3, a greater IVDMD and proportion of $\mathrm{CH}_{4}$ occurred in LF $(p<0.01)$, while total cumulative gas production, asymptotic gas production, and the proportion of $\mathrm{CO}_{2}$ were greater in HF. Regardless of whatever ration type was incubated, IVDMD, total cumulative gas production, asymptotic gas production, and the proportion of 
$\mathrm{CO}_{2}$ and $\mathrm{H}_{2}$ decreased against the gossypol addition, but the proportion of $\mathrm{CH}_{4}$ increased with the augmentation of the gossypol addition dose from 0 to $0.5 \mathrm{mg} / \mathrm{g}$.

Table 3. Effect of different gossypol addition levels on in vitro dry matter disappearance (IVDMD) and gas production kinetics of two rations after $48 \mathrm{~h}$ of incubation.

\begin{tabular}{|c|c|c|c|c|c|c|c|c|c|c|}
\hline \multirow{2}{*}{ Item $^{1}$} & & \multirow{2}{*}{ IVDMD } & \multirow{2}{*}{$\mathrm{GP}_{48}$} & \multicolumn{4}{|c|}{ Gas Production Kinetic } & \multicolumn{3}{|c|}{ Gas Composition (\%) } \\
\hline & & & & A & B & $\mathrm{C}$ & AGPR & $\mathrm{CO}_{2}$ & $\mathrm{CH}_{4}$ & $\mathbf{H}_{2}$ \\
\hline \multirow{2}{*}{ Ration } & $\mathrm{HF}^{2}$ & $53.5^{b}$ & 130.5 & 147.8 & 1.1 & 4.7 & $10.4^{\mathrm{a}}$ & $83.0^{a}$ & 15.6 & 0.2 \\
\hline & $\mathrm{LF}^{2}$ & $65.0^{\mathrm{a}}$ & 118.6 & 131.7 & 1.1 & 4.7 & $8.0^{\mathrm{b}}$ & $82.2^{b}$ & 16.3 & 0.2 \\
\hline SEM $^{3}$ & & 0.50 & 4.17 & 7.94 & 0.03 & 0.56 & 0.78 & 0.20 & 0.20 & 0.01 \\
\hline \multirow{4}{*}{$\begin{array}{c}\text { Gossypol } \\
\text { Dose (mg/g) }\end{array}$} & 0 & 60.6 & $140.5^{\mathrm{a}}$ & $156.3^{\mathrm{a}}$ & $1.1^{\mathrm{ab}}$ & 5.1 & 9.2 & $83.4^{\mathrm{a}}$ & $15.4^{\mathrm{b}}$ & $0.20^{a}$ \\
\hline & 0.25 & 59.4 & $128.2^{\mathrm{ab}}$ & $152.8^{\mathrm{a}}$ & $1.0^{b}$ & 5.4 & 9.0 & $83.0^{\mathrm{a}}$ & $16.0^{\mathrm{ab}}$ & $0.18^{a b}$ \\
\hline & 0.5 & 58.9 & $118.8^{b c}$ & $136.1^{\mathrm{ab}}$ & $1.0^{\mathrm{b}}$ & 4.9 & 8.0 & $82.0^{\mathrm{b}}$ & $16.7^{\mathrm{a}}$ & $0.16^{b}$ \\
\hline & 0.75 & 58.6 & $111.8^{\mathrm{c}}$ & $116.3^{b}$ & $1.2^{\mathrm{a}}$ & 3.6 & 10.4 & $81.6^{b}$ & $15.8^{\mathrm{b}}$ & $0.15^{b}$ \\
\hline SEM $^{3}$ & & 0.70 & 4.62 & 9.71 & 0.03 & 0.75 & 1.17 & 0.30 & 0.20 & 0.01 \\
\hline \multirow{5}{*}{$p$-Value } & Ration & $<0.01$ & 0.02 & 0.17 & 0.13 & 0.96 & 0.04 & 0.04 & 0.06 & 0.81 \\
\hline & Dose & 0.50 & $<0.01$ & 0.05 & 0.02 & 0.39 & 0.36 & $<0.01$ & 0.02 & 0.01 \\
\hline & $\mathrm{I}^{4}$ & 0.90 & 0.58 & 0.75 & 0.28 & 0.56 & 0.27 & 0.90 & 0.04 & 0.80 \\
\hline & $\mathrm{L}^{4}$ & 0.63 & $<0.01$ & $<0.01$ & 0.08 & 0.17 & 0.43 & $<0.01$ & 0.18 & $<0.01$ \\
\hline & $\mathrm{Q}^{4}$ & 0.18 & 0.54 & 0.44 & 0.01 & 0.32 & 0.19 & 0.90 & $<0.01$ & 0.40 \\
\hline
\end{tabular}

a,b,c Values in a column within the same class without a common superscript are significantly different ( $p<0.05) .{ }^{1}$ A, asymptotic gas production; B, sharpness parameter determining the curve shape of the cumulative gas production; $\mathrm{C}$, the time (h) at which half of $\mathrm{A}$ is reached; $A G P R$, the average gas production rate at half of $\mathrm{A} ; \mathrm{GP}_{48}$, cumulative gas production at 48 h; IVDMD, in vitro dry matter disappearance. ${ }^{2} \mathrm{HF}$, high-forage substrate; LF, low-forage substrate. ${ }^{3} \mathrm{SEM}$, standard error of the difference of the means. ${ }^{4} \mathrm{I}$, interaction effect; L, linear; Q, quadratic.

The soluble and easily degraded components in feeds are always utilized by rumen microbes first, followed by the insoluble but potentially digestible components. The greater IVDMD in LF than HF could be due to the degradation characteristics of ration components in the present study. Although the ration type presented a greater effect on IVDMD than the gossypol addition dose, the cumulative gas production, asymptotic gas production, and the proportion of $\mathrm{CO}_{2}$ and $\mathrm{H}_{2}$ showed a significant numeric decrease with the increase in the gossypol addition dose, and it noted that there was an obvious inhibitory effect of gossypol on rumen fermentation. The volume of cumulative gas production was positively correlated with dry matter degradability, but the current results show that cumulative gas production of HF was greater than LF, suggesting that gossypol presented a greater inhibitory effect on LF than $\mathrm{HF}$, and we speculated this could be due to the higher tolerance of rumen microbes in HF to gossypol. The results of the present study evidence that inclusion of gossypol could increase $\mathrm{CH}_{4}$ emissions which has not been reported before, and the promoting effect of gossypol on $\mathrm{CH}_{4}$ was more obvious in the LF group. The main pathway of $\mathrm{CH}_{4}$ synthesis in the rumen is reduction in $\mathrm{CO}_{2}$ and $\mathrm{H}_{2}$ by methanogens, which may explain the increase in $\mathrm{CH}_{4}$ with the decrease in $\mathrm{CO}_{2}$ and $\mathrm{H}_{2}$ when the gossypol addition dose was less than $0.5 \mathrm{mg} / \mathrm{g}$. The increase in methane production suggests that an appropriate amount of gossypol could promote the activity of methanogens and improve the utilization efficiency of $\mathrm{CO}_{2}$ and $\mathrm{H}_{2}$, but the mechanism is still unclear.

\subsection{Effect of Gossypol on In Vitro Rumen Fermentation Characteristics}

As shown in Table 4, pH and ammonia N were higher for HF than LF $(p<0.01)$, and the values increased with the augmentation of the gossypol addition dose. The concentrate of MCP was higher for HF than LF and decreased linearly with the increase in the gossypol dose. Total VFAs and the molar proportion of acetate and BCVFA were greater for HF than $\mathrm{LF}$, and the values increased with the augmentation of gossypol from 0.25 to $0.5 \mathrm{mg} / \mathrm{g}$. The proportion of butyrate and NGR were not affected by the type of ration, and the proportion 
of valerate and FE were not affected by ration type or the increase in the gossypol addition dose. Total disappearance of gossypol was higher in HF $(p<0.01)$, and it showed an obvious increase trend when gossypol increased from 0.25 to $0.5 \mathrm{mg} / \mathrm{g}$ but decreased significantly when gossypol was at $0.75 \mathrm{mg} / \mathrm{g}(p<0.01)$. Total disappearance of gossypol in all addition treatments could reach over $95 \%$ after $48 \mathrm{~h}$ of incubation.

Table 4. Effect of different gossypol addition levels on in vitro fermentation characteristics of two rations after $48 \mathrm{~h}$ of incubation.

\begin{tabular}{|c|c|c|c|c|c|c|c|c|c|c|c|c|c|}
\hline \multirow{2}{*}{ Item $^{1}$} & \multicolumn{2}{|l|}{ Ration } & \multirow{2}{*}{ SEM $^{3}$} & \multicolumn{4}{|c|}{ Gossypol (mg/g) } & \multirow{2}{*}{ SEM $^{3}$} & \multicolumn{5}{|c|}{$p$-Value } \\
\hline & $\mathrm{HF}^{2}$ & $\mathrm{LF}^{2}$ & & 0 & 0.25 & 0.5 & 0.75 & & Ration & Dose & $\mathrm{I}^{4}$ & $\mathrm{~L}^{4}$ & $\mathrm{Q}^{4}$ \\
\hline $\mathrm{pH}$ & $6.68^{a}$ & $6.61^{b}$ & 0.01 & $6.62^{b}$ & $6.64^{\mathrm{ab}}$ & $6.66^{\mathrm{ab}}$ & $6.67^{\mathrm{a}}$ & 0.02 & $<0.01$ & 0.09 & 0.99 & 0.01 & 0.87 \\
\hline $\mathrm{NH}_{3-} \mathrm{N}(\mathrm{mg} / \mathrm{dL})$ & $40.6^{\mathrm{a}}$ & $37.3^{b}$ & 0.31 & 39.3 & 37.9 & 39.0 & 39.2 & 0.40 & $<0.01$ & 0.22 & 0.05 & 0.91 & 0.07 \\
\hline $\mathrm{MCP}(\mu \mathrm{g} / \mathrm{mL})$ & 91.5 & 91.0 & 2.25 & $105.4^{\mathrm{a}}$ & $91.1^{\mathrm{b}}$ & $85.5^{b}$ & $83.0^{b}$ & 3.19 & 0.89 & $<0.01$ & 0.68 & $<0.01$ & 0.02 \\
\hline tVFA (mM) & $93.1^{\mathrm{a}}$ & $85.9^{b}$ & 1.09 & $89.6^{a b}$ & $90.8^{a}$ & $91.8^{a}$ & $85.8^{\mathrm{b}}$ & 1.55 & $<0.01$ & 0.06 & 0.53 & 0.15 & 0.03 \\
\hline Ace $(\%)$ & $51.9^{\mathrm{a}}$ & $47.2^{b}$ & 0.60 & $50.5^{\mathrm{a}}$ & $49.9^{a}$ & $51.1^{\mathrm{a}}$ & $46.9^{b}$ & 0.82 & $<0.01$ & 0.01 & 0.15 & 0.01 & 0.03 \\
\hline Pro (\%) & $18.7^{b}$ & $19.7^{\mathrm{a}}$ & 0.23 & $18.9^{b}$ & $20.3^{a}$ & $19.3^{b}$ & $18.5^{\mathrm{b}}$ & 0.33 & 0.01 & $<0.01$ & 0.23 & 0.10 & $<0.01$ \\
\hline But (\%) & 13.0 & 13.0 & 0.16 & $12.4^{\mathrm{b}}$ & $13.2^{\mathrm{a}}$ & $13.5^{\mathrm{a}}$ & $12.9^{a b}$ & 0.22 & 0.97 & 0.01 & 0.17 & 0.06 & $<0.01$ \\
\hline Val (\%) & 2.1 & 2.0 & 0.03 & 2.0 & 2.1 & 2.1 & 2.1 & 0.05 & 0.14 & 0.93 & 0.09 & 0.55 & 0.83 \\
\hline BCVFA (\%) & $6.0^{\mathrm{a}}$ & $5.3^{b}$ & 0.12 & $6.0^{\mathrm{a}}$ & $5.0^{\mathrm{b}}$ & $6.1^{a}$ & $5.6^{\mathrm{a}}$ & 0.16 & $<0.01$ & $<0.01$ & 0.03 & 0.96 & 0.13 \\
\hline NGR & 3.6 & 3.6 & 0.03 & $3.6^{b}$ & $3.5^{b}$ & $3.8^{\mathrm{a}}$ & $3.6^{b}$ & 0.04 & 0.62 & $<0.01$ & 0.77 & 0.21 & 0.58 \\
\hline FE & 0.75 & 0.78 & 0.01 & 0.79 & 0.76 & 0.75 & 0.76 & 0.012 & 0.14 & 0.31 & 0.31 & 0.18 & 0.34 \\
\hline $\mathrm{D}_{\mathrm{G}}(\%)$ & $97.6^{a}$ & $95.9^{b}$ & 0.12 & - & $96.8^{b}$ & $97.7^{\mathrm{a}}$ & $95.8^{c}$ & 0.15 & $<0.01$ & $<0.01$ & 0.66 & $<0.01$ & $<0.01$ \\
\hline
\end{tabular}

The optimal rumen $\mathrm{pH}$ plays a key role in the maintenance of normal rumen function, and the appropriate $\mathrm{pH}$ in rumen liquid for ruminal microbes ranged from 6.6 to 6.8 [29]. In the present study, $\mathrm{pH}$ values ranged from 6.61 to 6.68 and were within the acceptable limits. The concentration of ammonia $\mathrm{N}$ is an essential indicator of the $\mathrm{N}$-metabolism level in the rumen. As an intermediate product of rumen fermentation, ammonia $\mathrm{N}$ is either the nitrogen source of MCP synthesis or the end product of dietary protein metabolism. The ammonia $\mathrm{N}$ concentration in the present study increased along with the augmentation of the gossypol addition dose, but MCP linearly decreased against the gossypol addition $(p<0.01)$, suggesting that the conversion efficiency of ammonia N to MCP was affected by the detrimental effect of gossypol on rumen microbes.

The VFAs are end products of rumen fermentation which provide the main metabolizable energy resource for host ruminants [30]. Total VFAs concentration was greater in the HF than the LF group in the present study, depending on the difference in the nutrient density in the rations. Total VFAs production of both rations showed a numerical increase with the augmentation of gossypol from 0 to $0.5 \mathrm{mg} / \mathrm{g}$, which confirmed that the gossypol addition dose below $0.5 \mathrm{mg} / \mathrm{g}$ could promote the rumen fermentation efficiency. About $80 \%$ maintenance energy of ruminants was provided by acetate, propionate, and butyrate [31]. Acetate is an essential VFA for the synthesis of milk fat, while propionate is an important VFA for the synthesis of milk lactose [32]. The greater acetate concentration in HF than LF was due to the greater content of fiber in HF, suggesting the fermentation pattern of the HF ration belonged to acetate fermentation. The greater propionate concentration in LF than HF was due to the dominant position of the soluble carbohydrate (e.g., starch) fermentation of LF, suggesting the fermentation pattern of the LF ration belonged to propionate fermentation. Regardless of whatever ration type was incubated, the molar proportion of propionate decreased while molar proportions of acetate and butyrate increased in the gossypol addition group in comparison with the control. The present study observed an inhibitory effect of the gossypol addition on the activity of ruminal lactate-utilizing bacteria, such as S. ruminantium which plays a key role in the conversion of lactate to propionate. The molar propionate proportion showed a significant decrease 
when the gossypol addition dose increased from 0.25 to $0.75 \mathrm{mg} / \mathrm{g}$, suggesting that there could be a detrimental effect of the gossypol addition on milk production by providing less glucogenic energy for the formation of milk lactose. Moss et al. [33] found that there was a positive relationship between methane production and the molar portion of acetate and butyrate due to a competition existing between propionate formation and the synthesis of methane from hydrogen in the rumen. The decrease in propionate and the increase in acetate and butyrate proportions were associated with the increase in methane production in the present study. Until now, there has been no report about the methane-promoting effect of gossypol, and further animal trials are necessary in the near future to be conducted to confirm the present in vitro results. The total VFAs and disappearance of gossypol decreased significantly when gossypol was at $0.75 \mathrm{mg} / \mathrm{g}$, suggesting that there was an obvious inhibitory effect of gossypol on rumen fermentation when it exceeded the safety limit amount of the European Union $(500 \mathrm{mg} / \mathrm{kg}$ ). In addition, the total disappearance of gossypol was higher in HF than LF, suggesting that gossypol degradation could relate to the process of fiber degradation, and the ration with a high portion of forage was more conducive to the degradation and transformation of gossypol by rumen microbes.

\subsection{Effect of Gossypol on Rumen Microbial Population}

F. succinogenes, $R$. flavefaciens, and $R$. albus are the main fibrolytic bacteria in the rumen [34]. As shown in Table 5, the population sizes of target fibrolytic bacteria in the rumen fluid were greater in HF than LF and ranked as $R$. flavefaciens $>F$. succinogenes $>$ R. albus. According to Michalet-Doreau et al. [35,36] and Koike et al. [37], F. succinogenes was the most dominant species among the three cellulolytic bacteria, whereas $R$. albus was the least abundant species, which is consistent with results in the present study. Compared with the control, the supplementation of rations with gossypol decreased the population of F. succinogenes and R. albus $(p<0.01)$, while the population of $R$. flavefaciens was positively influenced by the addition of gossypol, implicating that fibrolytic bacteria might show different tolerances to gossypol, and gossypol was not harmful to all microbes in the rumen. In addition, the population of $F$. succinogenes and $R$. flavefaciens showed a numeric increase with the increase in the gossypol addition dose, and this likely implicates that there could be a promoting effect of gossypol on the population of $F$. succinogenes and R. flavefaciens by utilizing gossypol and its degradation products as growth resources.

Table 5. Effect of different gossypol addition levels on rumen microbial population of two rations after $48 \mathrm{~h}$ of incubation (log10 gene copy number/ mL of DNA extract).

\begin{tabular}{|c|c|c|c|c|c|c|c|c|c|c|c|c|c|}
\hline \multirow{2}{*}{ Item } & \multicolumn{2}{|c|}{ Ration } & \multirow{2}{*}{ SEM $^{2}$} & \multicolumn{4}{|c|}{ Gossypol (mg/g) } & \multirow{2}{*}{ SEM $^{2}$} & \multicolumn{5}{|c|}{$p$-Value } \\
\hline & $\mathrm{HF}^{1}$ & $\mathbf{L F}^{1}$ & & 0 & 0.25 & 0.5 & 0.75 & & Ration & Dose & $\mathrm{I}^{3}$ & $\mathrm{~L}^{3}$ & $Q^{3}$ \\
\hline F. succinogenes & $6.75^{a}$ & $6.50^{b}$ & 0.025 & $7.15^{a}$ & $6.34^{\mathrm{d}}$ & $6.48^{c}$ & $6.61^{b}$ & 0.034 & $<0.01$ & $<0.01$ & 0.05 & $<0.01$ & $<0.01$ \\
\hline R. flavefaciens & 6.78 & 6.68 & 0.080 & $6.67^{b}$ & $6.73^{b}$ & $6.41^{b}$ & $7.11^{\mathrm{a}}$ & 0.110 & 0.41 & $<0.01$ & 0.99 & 0.08 & 0.02 \\
\hline R. albus & 6.32 & 6.25 & 0.021 & $6.42^{\mathrm{a}}$ & $6.28^{b}$ & $6.24^{b}$ & $6.21^{b}$ & 0.026 & 0.07 & $<0.01$ & 0.82 & $<0.01$ & 0.11 \\
\hline B. fibrisolvens & $8.50^{b}$ & $8.58^{a}$ & 0.016 & $8.72^{\mathrm{a}}$ & $8.54^{b}$ & $8.49^{b}$ & $8.40^{c}$ & 0.022 & $<0.01$ & $<0.01$ & 0.60 & $<0.01$ & 0.11 \\
\hline P. ruminicola & $7.18^{b}$ & $7.26^{\mathrm{a}}$ & 0.022 & $7.40^{\mathrm{a}}$ & $7.01^{\mathrm{d}}$ & $7.25^{b}$ & $7.14^{\mathrm{c}}$ & 0.028 & 0.03 & $<0.01$ & 0.02 & $<0.01$ & $<0.01$ \\
\hline S. ruminantium & $6.09^{b}$ & $6.20^{\mathrm{a}}$ & 0.028 & $6.23^{a}$ & $6.05^{b}$ & $6.15^{\mathrm{ab}}$ & $6.15^{a b}$ & 0.034 & 0.01 & 0.06 & 0.62 & 0.51 & 0.06 \\
\hline Protozoa & $4.97^{\mathrm{a}}$ & $4.89^{b}$ & 0.016 & $4.76^{c}$ & $4.87^{b}$ & $4.94^{\mathrm{b}}$ & $5.15^{\mathrm{a}}$ & 0.022 & $<0.01$ & $<0.01$ & 0.82 & $<0.01$ & 0.07 \\
\hline Fungi & $3.36^{\mathrm{a}}$ & $3.21^{\mathrm{b}}$ & 0.016 & $3.45^{\mathrm{a}}$ & $3.35^{b}$ & $3.26^{c}$ & $3.09^{\mathrm{d}}$ & 0.023 & $<0.01$ & $<0.01$ & 0.31 & $<0.01$ & 0.14 \\
\hline Total bacteria & $9.82^{b}$ & $9.93^{a}$ & 0.035 & $9.78^{b}$ & $9.83^{b}$ & $9.86^{b}$ & $10.04^{\mathrm{a}}$ & 0.049 & $<0.01$ & $<0.01$ & $<0.01$ & $<0.01$ & 0.04 \\
\hline
\end{tabular}

a,b,c,d Values in a line within the same class without a common superscript are significantly different $(p<0.05) .{ }^{1}$ HF, high-forage substrate;

LF, low-forage substrate. ${ }^{2}$ SEM, standard error of the difference of the means. ${ }^{3}$ I, interaction effect; L, linear; $Q$, quadratic.

The population of B. fibrisolvens and P. ruminicola in the present study was significantly higher in LF than HF. Both Butyrivibrio and Prevotella sp. in the present study represented considerable amounts of bacteria in the two types of ration, suggesting there was a great deal of metabolic diversity in these genera. Most ruminal Butyrivibrio genera play a key role in the degradation of starch and pectins and can use urea and ammonia as nitrogen sources [38]. However, B. fibrisolvens in the present study seems to be capable of utilizing not only starch and protein but also cellulose. P. ruminicola plays a key role in ruminal 
protein degradation and some strains can ferment xylan, pectin, and starch instead of cellulose. The population of $B$. fibrisolvens and P. ruminicola had an obvious decrease with the addition of gossypol $(p<0.01)$, and it corresponded to the decrease in the concentration of ammonia $\mathrm{N}$ in comparison with the control, likely suggesting there was a detrimental effect of gossypol on the population of proteolytic bacteria.

S. ruminantium has been found to utilize a wide range of substrates, and it plays a key role in the synthesis of propionate, malate, and lactate from primary fermentation products such as pyruvate and succinate in the rumen $[39,40]$. Hence, the higher population of S. ruminantium in the LF group could participate in the utilization of lactic acid produced within rumen fermentation, and the increasing $S$. ruminantium populations with the increase in the gossypol addition dose from 0.25 to $0.5 \mathrm{mg} / \mathrm{g}$ could relate to the decrease in gossypol by utilization.

Both protozoa and total bacteria increased linearly with the augmentation of the gossypol addition dose, whereas the population of fungi decreased significantly. This suggests that fungi were more sensitive to gossypol than bacteria and protozoa, and there could be a detrimental effect of gossypol on the growth and reproduction of fungi. Additionally, protozoa can secret enzymes which degrade the cell walls of fungi [41], and they compete with fungi for nutrients [42]. Consequently, the increase in protozoa could also inhibit the number of fungi. In the present study, there was an interaction effect of the ration and gossypol on the population of total bacteria, as shown in Figure 2. The total bacteria population of LF increased significantly when the gossypol addition level reached $0.75 \mathrm{mg} / \mathrm{g}$, while that of the HF group decreased obviously. This suggests that the detrimental effect of gossypol on rumen bacteria was more obvious on the LF ration than HF when the gossypol addition dose exceeded the safety limit. We speculate that the bacteria of the LF group survived with the greater degradation and transformation ability of gossypol, and then alleviated the toxicity of the excess gossypol.

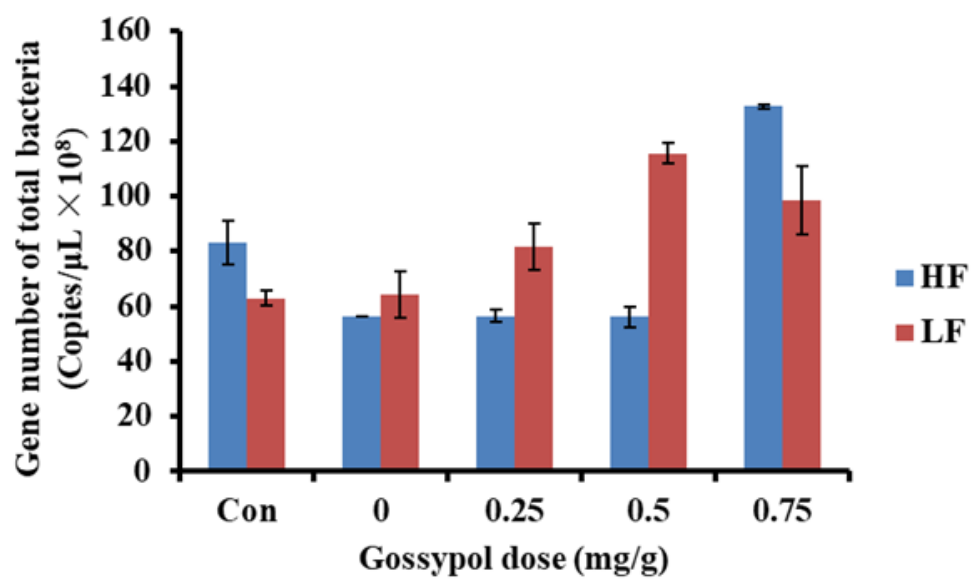

Figure 2. Interaction effect of gossypol dose and ration on the population of total bacteria (HF, Chinese wildrye hay/corn meal—3:2; LF, Chinese wildrye hay/corn meal—2:3).

In present study, the population of both fibrolytic and amylolytic bacteria showed a trend towards increased levels with the increase in the gossypol addition dose from 0.25 to $0.5 \mathrm{mg} / \mathrm{g}$, suggesting that energy metabolism could play an essential role in the process of gossypol detoxification by rumen bacteria, and this was also demonstrated by the previous results of Yang et al. [43].

\section{Conclusions}

Except for the ration type, the addition of gossypol affected in vitro fermentation characteristics in terms of reduced cumulative gas production and microbial protein, but it increased ammonia N and VFA concentrations. The gossypol addition increased the 
population of rumen bacteria responsible for fiber and starch metabolism. Although mixed rumen microbes showed a high ability to degrade gossypol (>0.95), there was an obvious detrimental effect of gossypol on the activity of rumen microbes and rumen fermentation when the gossypol inclusion exceeded $0.5 \mathrm{mg} / \mathrm{g}$ in rations, and such inhibitory effect was more pronounced on the low-forage than the high-forage ration.

Author Contributions: Conceptualization, W.-K.W. and Y.-L.W.; methodology, W.-K.W.; software, W.-J.L.; validation, Q.-C.W.; formal analysis, W.-K.W.; investigation, Y.-L.W.; resources, W.-J.L. and Q.-C.W.; data curation, W.-K.W.; writing-original draft preparation, W.-K.W.; writing-review and editing, S.-L.L. and H.-J.Y.; visualization, H.-J.Y.; supervision, H.-J.Y.; project administration, H.-J.Y.; funding acquisition, S.-L.L. All authors have read and agreed to the published version of the manuscript.

Funding: This research was funded by Key Research and Development Project of Ningxia Hui Autonomous Region, grant number 2018BBF33006.

Institutional Review Board Statement: The study was conducted according to the guidelines of the Declaration of Helsinki, and approved by the Institutional Review Board of Institutional Animal Care Committee of China Agricultural University (protocol code CAU20171014-1 and date of approval 25 June 2020).

Data Availability Statement: The data presented in this study are available on request from the corresponding author.

Conflicts of Interest: The authors declare no conflict of interest.

\section{References}

1. Santos, J.E.P.; Villaseňor, M.; Depeters, E.J.; Robinson, P.H.; Baldwin, B.C., Jr. Type of cottonseed and level of gossypol in diets of lactating dairy cows: Effects on lactation performance and plasma gossypol. J. Dairy Sci. 2002, 85, 1491-1501. [CrossRef]

2. Wang, X.; Howell, C.P.; Chen, F.; Yin, J.J.; Jiang, Y.M. Gossypol-A polyphenolic compound from cotton plant. Adv. Food Nutr. Res. 2009, 58, 215-263. [PubMed]

3. Reiser, R.; Fu, H.C. The mechanism of gossypol detoxification by ruminant animals. J. Nutr. 1962, 76, 215-218. [CrossRef]

4. Feng, Y.; Wang, Y. The nutrition value and metabolism of cottonseed in ruminants. Feed Res. 2011, 4, 13-16.

5. Câmara, A.C.L.; Vale, A.M.D.; Mattoso, C.R.S.; Melo, M.M.; Soto-Blanco, B. Effects of gossypol from cottonseed cake on the blood profile in sheep. Trop. Anim. Health Pro. 2016, 48, 1-6. [CrossRef]

6. Zbidah, M.; Lupescu, A.; Shaik, N.; Lang, F. Gossypol-induced suicidal erythrocyte death. Toxicology 2012, 302, 101-105. [CrossRef] [PubMed]

7. Higginbotham, G.E.; Santos, J.E.P.; Depeters, E.J. Effects of pelleting whole cottonseed on plasma gossypol, rumen metabolites, and performance of lactating dairy cows. Prof. Anim. Sci. 2004, 20, 413-421. [CrossRef]

8. Santos, J.; Villasenor, M.; Robinson, P.H.; DePeters, E.J.; Holmberg, C.A. Type of cottonseed and level of gossypol in diets of lactating dairy cows: Plasma gossypol, health, and reproductive performance. J. Dairy Sci. 2003, 86, 892-905. [CrossRef]

9. Chenoweth, P.J.; Chase, C.C., Jr.; Risco, C.A.; Larsen, R.E. Characterization of gossypol-induced sperm abnormalities in bulls. Theriogenology 2000, 53, 1193-1203. [CrossRef]

10. Hassan, M.E.; Smith, G.W.; Ott, R.S.; Faulkner, D.B.; Firkins, L.D.; Ehrhart, E.J.; Schaeffer, D.J. Reversibility of the reproductive toxicity of gossypol in peripubertal bulls. Theriogenology 2004, 61, 1171-1179. [CrossRef]

11. Yuan, Y.Y.; Shi, Q.X. Inhibition of hamster sperm acrosomal enzyme by gossypol is closely associated with the decrease in fertilization capacity. Contraception 2005, 62, 229-236. [CrossRef]

12. Knutsen, H.K.; Barregård, L.; Bignami, M.; Brüschweiler, B.; Ceccatelli, S.; Dinovi, M.; Edler, L.; Kraupp, B.G.; Hogstrand, H.; Hoogenboom, L.; et al. Presence of free gossypol in whole cottonseed. EFSA J. 2017, 15, 4850-4865.

13. Russell, J.B.; Rychlik, J.L. Factors that alter rumen microbial ecology. Science 2001, 292, 1119-1122. [CrossRef]

14. Menke, K.H.; Steingass, H. Estimation of the energetic feed value obtained from chemical analysis and in vitro gas production using rumen fluid. Anim. Res. Dev. 1988, 28, 7-55.

15. Zhang, D.F.; Yang, H.J. In vitro ruminal methanogenesis of a hay-rich substrate in response to different combination supplements of nitrocompounds; pyromellitic diimide and 2-bromoethanesulphonate. Anim. Feed Sci. Technol. 2011, 163, 20-32. [CrossRef]

16. AOAC. Official Methods of Analysis of AOAC International, 17th ed.; Association of Official Analytical Chemists: Gaithersburg, MD, USA, 2005.

17. Van Soest, P.J.; Robertson, J.B.; Lewis, B.A. Methods for dietary fiber, neutral detergent fiber, and nonstarch polysaccharides in relation to animal nutrition. J. Dairy Sci. 1991, 74, 3583-3597. [CrossRef]

18. Verdouw, H.; Vanechteld, C.J.A.; Dekkers, E.M.J. Ammonia determination based on indophenol formation with sodium salicylate. Water Res. 1978, 12, 399-402. [CrossRef] 
19. Cui, J.H.; Yang, H.J.; Yu, C.Q.; Bai, S.; Wu, T.T.; Song, S.S.; Sun, W.; Shao, X.M.; Jiang, L.S. Effect of urea fertilization on biomass yield, chemical composition, in vitro rumen digestibility and fermentation characteristics of straw of highland barley planted in Tibet. J. Agric. Sci. 2016, 154, 151-164. [CrossRef]

20. Groot, J.C.; Cone, J.W.; Williams, B.A. Multiphasic analysis of gas production kinetics for in vitro fermentation of ruminant feeds. Anim. Feed Sci. Technol. 1996, 64, 77-89. [CrossRef]

21. SAS. Statistical Analytical System (SAS) Users Guides: Statistics; Version 8.2; Statistica Analysis Institute: Cary, NC, USA, 1999.

22. Ørskov, E.R. Manipulation of rumen fermentation for maximum food utilization. World Rev. Nutr. Diet. 1975, $22,152-182$.

23. Zhong, R.Z. Performance and Composition of Milk Fat of Holstein Cows Fed Whole Cottonseed During early Lactation. Master's Thesis, Hebei Agricultural University, Shijiazhuang, China, 2007.

24. Denman, S.E.; Mc Sweeney, C.S. Development of a real-time PCR assay for monitoring anaerobic fungal and cellulolytic bacterial populations within the rumen. FEMS Microbiol. Ecol. 2006, 58, 572-582. [CrossRef] [PubMed]

25. Koike, S.; Kobayashi, Y. Development and use of competitive PCR assays for the rumen cellulolytic bacteria: Fibrobacter succinogenes, Ruminococcus albus and Ruminococcus flavefaciens. FEMS Microbiol. Lett. 2001, 204, 361-366. [CrossRef]

26. Yang, S. Effect of Soybean Oil and Linseed Oil Supplementation on Population of Ruminal Bacteria and Fermentation Parameters in Dairy Cows. Ph.D. Thesis, Chinese Academy of Agricultural Sciences, Beijing, China, 2007.

27. Stevenson, D.M.; Weimer, P. Dominance of Prevotella and low abundance of classical ruminal bacterial species in the bovine rumen revealed by relative quantification real-time PCR. Appl. Microbiol. Biotechnol. 2007, 75, 165-174. [CrossRef]

28. Sylvester, J.T.; Karnati, S.K.; Yu, Z.; Morrison, M.; Firkins, J.L. Development of an assay to quantify rumen ciliate protozoal biomass in cows using realtime PCR. J. Nutr. 2004, 134, 3378-3384. [CrossRef] [PubMed]

29. DePeters, E.J.; Bath, D.L. Canola meal vensus cottonseed meal as the protein supplementin dairy diets. J. Dairy Sci. 1986, 58, 572-582.

30. Van Soest, P.J. Nutritional Ecology of the Ruminant; Comstock, Cornell University Press: NewYork, NY, USA, 1982.

31. Bergman, E.N. Energy contribution of volatile fatty acids from the gastrointestinal tract in various species. Physiol. Rev. 1990, 70, 567-590. [CrossRef]

32. Herdt, T.H. Metabolic diseases of ruminant livestock: Fuel homeostasis in the ruminants. Vet. Clin. North Am. Food Anim. 1988, Pract4, 213-231. [CrossRef]

33. Moss, A.R.; Jouany, J.; Newbold, J. Methane Production by Ruminants: Its Contribution to Global Warming; Annales de Zootechnie; Institut National de la Recherché Agronomique: Paris, France, 2000.

34. Forsberg, C.W.; Cheng, K.J.; White, B.A. Polysaccharide degradation in the rumen and large intestine. In Gastrointestinal Microbiology; Mackie, R.I., White, B.A., Eds.; Springer: Boston, MA, USA, 1997; pp. 319-379.

35. Michalet-Doreau, B.; Fernandez, I.; Peyron, C.; Millet, L.; Fonty, G. Fibrolytic activities and cellulolytic bacterial community structure in the solid and liquid phases of rumen contents. Reprod. Nutr. Dev. 2001, 41, 187-194. [CrossRef]

36. Michalet-Doreau, B.; Fernandez, I.; Fonty, G. A comparison of enzymatic and molecular approaches to characterize the cellulolytic microbial ecosystems of the rumen and the cecum. J. Anim. Sci. 2002, 80, 790-796. [CrossRef] [PubMed]

37. Koike, S.; Yoshitani, S.; Kobayashi, Y.; Tanaka, K. Kinetics of in sacco fiber-attachment of representative ruminal cellulolytic bacteria monitored by competitive PCR. J. Dairy Sci. 2003, 86, 1429-1435. [CrossRef]

38. Willems, A.; Collins, M.D. Butyrivibrio. In Bergey's Manual of Systematics of Archaea and Bacteria; Whitman, W.B., Ed.; John Wiley \& Sons: New York, NY, USA, 2015; pp. 1-20.

39. Hungate, R.E. The Rumen and its Microbes; Academic Press: New York, NY, USA, 1966.

40. Evans, J.D.; Martin, S.A. Factors affecting lactate and malate utilization by Selenomonas ruminantium. Appl. Environ. Microbiol. 1997, 63, 4853-4858. [CrossRef] [PubMed]

41. Morgavi, D.P.; Sakurada, M.; Tomita, Y.; Onodera, R. Presence in rumen bacterial and protozoal populations of enzymes capable of degrading fungal cell walls. Microbiology 1994, 140, 631-636. [CrossRef] [PubMed]

42. Williams, A.G.; Lloyd, D. Biological activities of symbiotic and parasitic protozoa and fungi in low-oxygen environments. Adv. Microb. Ecol. 1993, 13, 211-262.

43. Yang, X.; Guo, J.L.; Sun, J.Y. Biodegradation of free-gossypol by a new fungus isolated from cotton planted soil. Afr. J. Microbiol. Res. 2011, 5, 3066-3072. 